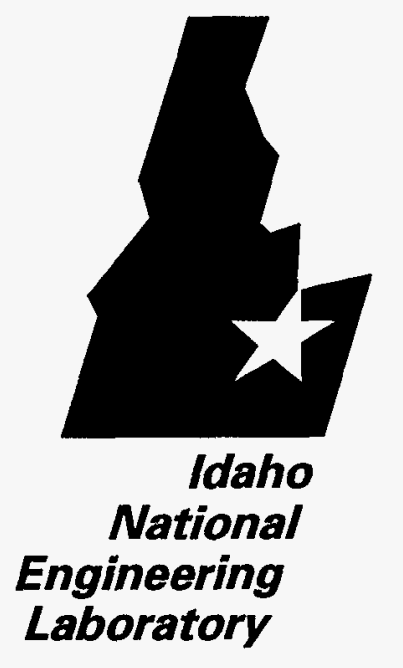

$\therefore \quad$ FIVED

OCT 271995

OSTI

May 1995

Pyrochemical Separation of Radioactive Components from Inert Materials in ICPP High-Level Calcined Waste

J. A. Del Debbio

L. O. Nelson

T. A. Todd 
This report was prepared as an account of work sponsored by an agency of the United States Government. Neither the United States Government nor any agency thereof, nor any of their employees, makes any warranty, express or implied, or assumes any legal liability or responsibility for the accuracy, completeness, or usefulness of any information, apparatus, product, or process disclosed, or represents that its use would not infringe privately owned rights. Reference herein to any specific commercial product, process, or service by trade name, trademark, manufacturer, or otherwise does not necessarily constitute or imply its endorsement, recommendation, or favoring by the United States Government or any agency thereof. The views and opinions of authors expressed herein do not necessarily state or reflect those of the United States Government or any agency thereof.

\title{
Pyrochemical Separation of Radioactive Components from Inert Materials in ICPP High-Level Calcined Waste
}

\author{
J. A. Del Debbio
}

L. O. Nelson

T. A. Todd

Published May 1995

\section{Idaho National Engineering Laboratory Lockheed Idaho Technologies Company Idaho Falls, Idaho 83415}

\author{
Prepared for the \\ U.S. Department of Energy \\ Otflce of Nuclear Energy \\ Under DOE Idaho Operations Office \\ Contract DE-AC07-941D13223
}




\section{DISCLAMMER}

Portions of this document may be illegible in electronic image products. Images are produced from the best available original document. 


\begin{abstract}
Separation of radioactive components from inert materials in high-level calcined wastes has the potential of significantly reducing the cost of final disposal of the high-level wastes in a federal repository. Pyrochemical methods for separating actinides and fission products from nonradioactive components have been evaluated. Compared to aqueous processes, pyrochemical processes generate small volumes of aqueous wastes and do not require calcine dissolution.

Removal of $>99 \%$ of the ${ }^{137} \mathrm{Cs}$ and ${ }^{99} \mathrm{Tc}$ by high temperature volatilization at $1000-1170^{\circ} \mathrm{C}$ was demonstrated for all calcine types. Separation of inert metal oxides $\left(\mathrm{ZrO}_{2}\right.$ and $\left.\mathrm{Al}_{2} \mathrm{O}_{3}\right)$ from simulated zirconia calcine was demonstrated by molten salt extraction with $\mathrm{CaCl}_{2}$ and by reduction to $\mathrm{Al}$ and $\mathrm{Zr}$ with $\mathrm{Ca}$ in molten $\mathrm{CaCl}_{2}$. It is expected that actinide oxides in actual calcine would also be removed. Although tests indicated that $>95 \%$ of the $\mathrm{Al}$ and $\mathrm{Zr}$ was removed from the calcine, separation of the oxides and the metals from the molten salt by filtration was incomplete. Extensive process development would be required to demonstrate the feasibility of pyroprocessing zirconia calcine.

Chlorination of simulated alumina calcine with $\mathrm{CO} / \mathrm{Cl}_{2}$ mixtures resulted in an $86 \mathrm{wt} \%$ loss due to the conversion $\mathrm{Al}_{2} \mathrm{O}_{3}$ to $\mathrm{CO}_{2}$ and $\mathrm{AlCl}_{3}$, which is volatile. Reaction rates were rapid, and separation of reaction products from the calcine residue was achieved. Chlorination of alumina calcine to separate actinides from inert materials may be feasible. Chlorination of zirconia calcine to remove $\mathrm{Al}$ and $\mathrm{Zr}$ as volatile chlorides resulted in a $14 \mathrm{wt} \%$ gain due to the conversion of $\mathrm{CaF}_{2}$ to $\mathrm{CaCl}_{2}$ and $\mathrm{Al}_{2} \mathrm{O}_{3}$ to $\mathrm{AlF}_{3}$. Thus, chlorination of zirconia calcines to remove inert materials is not feasible.
\end{abstract}





\section{SUMMARY}

Radioactive components represent less than $1 \mathrm{wt} \%$ of the high-level calcined wastes being stored at the Idaho Chemical Processing Plant. Thus, compared to direct immobilization, separation of the highlevel waste (HLW) fraction from the nonradioactive constituents has the potential of reducing disposal costs by minimizing the volume of waste requiring final disposal. Aqueous processes for separating actinides and fission products from nonradioactive components using solvent extraction and ion exchange methods are being developed. These methods require calcine dissolution in nitric acid and generate large volumes of aqueous wastes. Pyrochemical methods, which generate small quantities of aqueous wastes and do not require calcine dissolution have been evaluated as alternatives to aqueous processes.

Greater than $90 \mathrm{wt} \%$ of zirconia calcine consists of $\mathrm{CaF}_{2}, \mathrm{Al}_{2} \mathrm{O}_{3}$ and $\mathrm{ZrO}_{2}$. Alumina calcine contains approximately $90 \mathrm{wt} \% \mathrm{Al}_{2} \mathrm{O}_{3}$. Two flowsheets for separating actinides and fission products from inert materials in zirconia calcine using molten salt methods have been developed by Lawrence Livermore National Laboratory (LLNL) and Lockheed Idaho Technologies Company (LITCO). A flowsheet for removing $\mathrm{Al}_{2} \mathrm{O}_{3}$ and other inerts from alumina calcine as volatile chlorides has been developed by LITCO. Removal of ${ }^{137} \mathrm{Cs}$ and ${ }^{99} \mathrm{Tc}$ by high temperature volatilization is common to all flowsheets. Tests with all calcine types, including actual calcine generated at the New Waste Calcination Facility (NWCF) indicated that $>99 \%$ of the cesium and technetium was removed by heating at $1000-1170^{\circ} \mathrm{C}$ for 5 hours.

The first zirconia flowsheet tested involves contacting the calcine with molten $\mathrm{CaCl}_{2}$ at $800-900^{\circ} \mathrm{C}$ to dissolve the $\mathrm{CaF}_{2}$ and to separate the actinide and inert metal oxides by filtration. The combined oxides are then chlorinated with $\mathrm{CCl}_{4}$ and the inert metal chlorides are separated from the actinide chlorides by volatilization. The actinide chlorides are reduced with $\mathrm{Ca}$ and converted to a metallic waste form or converted to oxides for immobilization in glass. The fission products (principally ${ }^{90} \mathrm{Sr}$ ) remain in the salt which is disposed of as low-level waste (LLW). The results of $\mathrm{CaCl}_{2}$ wash tests conducted by LLNL with simulated zirconia calcine indicated that $>99 \%$ of the $\mathrm{ZrO}_{2}$ and $\mathrm{Al}_{2} \mathrm{O}_{3}$ was separated by filtration and that $75-90 \%$ of the $\mathrm{F}$ dissolved in the $\mathrm{CaCl}_{2}$. However, $60 \%$ of the molten $\mathrm{CaCl}_{2}$ did not pass through the filter and filtration rates were too slow to be practical.

The second zirconia flowsheet tested is the calcium reduction flowsheet in which the calcine is reacted with $\mathrm{Ca}$ in molten $\mathrm{CaCl}_{2}$ to reduce the actinide and inert metal oxides to metals. The metals are separated from the molten salt by filtration, and chlorinated with $\mathrm{Cl}_{2}$ at $600^{\circ} \mathrm{C}$ to separate volatile inert metal chlorides from actinide chlorides. The other process steps are similar to the calcium chloride wash flowsheet. Calcine reduction tests conducted with simulated zirconia calcine at $800-1000^{\circ} \mathrm{C}$ resulted in $100 \%$ reduction of $\mathrm{Al}_{2} \mathrm{O}_{3}$ and $95 \%$ reduction of $\mathrm{ZrO}_{2}$. Filtration of the molten salt to remove the $\mathrm{Al}$ and $\mathrm{Zr}$ metal particulates was very slow and resulted in only partial separation. The addition of $\mathrm{Zn}$ (m.p. $400^{\circ} \mathrm{C}$ ) to coalesce the metals into a metallic button was unsuccessful. At least $78 \%$ of the Sr was not reduced and remained in the filtered salt. In an actual process, the salt would be disposed of as a LLW.

The process for treating alumina calcine consists of chlorination of inert oxides with $\mathrm{CCl}_{4}$ or $\mathrm{CO} / \mathrm{Cl}_{2}$ at $600^{\circ} \mathrm{C}$ to separate them from radioactive components as volatile chlorides. The principal products would be $\mathrm{AlCl}_{3}$ and $\mathrm{BCl}_{3}$ with traces of $\mathrm{FeCl}_{3}$ and $\mathrm{ZrCl}_{4}$. The inert chlorides are then oxidized and converted into a LLW waste glass. The nonvolatile actinide chlorides and fission products are reduced with $\mathrm{Ca}$ and oxidized for conversion into a $\mathrm{HLW}$ glass. Experiments in which simulated alumina calcine was chlorinated with $\mathrm{CO} / \mathrm{Cl}_{2}$ in $\mathrm{Ar}$ at $600^{\circ} \mathrm{C}$ resulted in $100 \%$ conversion of $\mathrm{Al}_{2} \mathrm{O}_{3}$ to $\mathrm{AlCl}_{3}$ and $\mathrm{CO}_{2}$. Analysis of the residual calcine indicated that $100 \%$ of the cesium volatilized under these test conditions, 
probably as $\mathrm{CsCl}_{2}$. This indicates the importance of removing cesium upstream of the chlorination process in order to separate radioactive components from inert materials.

Although a chlorination process for treating alumina calcine may be feasible, application of pyrochemical methods for separating radioactive components from inert materials for all calcine types would be difficult. Many of the process steps in the proposed flowsheets have not been demonstrated, and, compared to aqueous processes, a much longer development time would be required to determine feasibility. Therefore, it is recommended that further development of pyrochemical methods should not be considered. 


\section{CONTENTS}

ABSTRACT $\ldots \ldots \ldots \ldots \ldots \ldots \ldots \ldots \ldots \ldots \ldots \ldots \ldots \ldots \ldots \ldots \ldots \ldots \ldots \ldots \ldots$

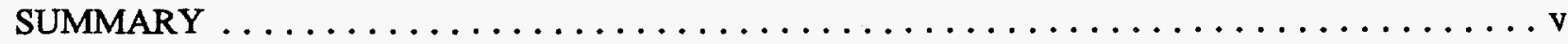

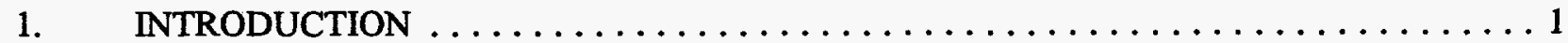

2. CALCINE CHARACTERIZATION $\ldots \ldots \ldots \ldots \ldots \ldots \ldots \ldots \ldots \ldots \ldots \ldots$

3. PROCESS FLOWSHEET DEVELOPMENT $\ldots \ldots \ldots \ldots \ldots \ldots \ldots \ldots \ldots$

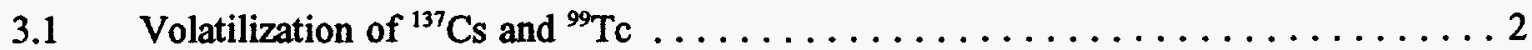

3.2 Calcium Chloride Wash Process for Treating Zirconia Calcines . . . . . . . . 4

3.3 Calcium Reduction Process for Treating Zirconia Calcines $\ldots \ldots \ldots \ldots \ldots \ldots$

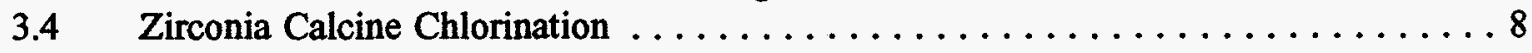

3.5 Chlorination of Alumina Calcine $\ldots \ldots \ldots \ldots \ldots \ldots \ldots \ldots \ldots \ldots$

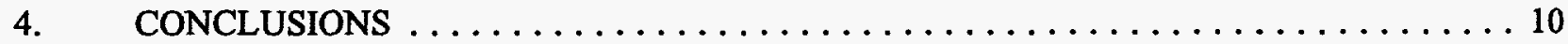

5. REFERENCES $\ldots \ldots \ldots \ldots \ldots \ldots \ldots \ldots \ldots \ldots \ldots \ldots \ldots \ldots \ldots \ldots \ldots$

\section{FIGURES}

1. Calcium Chloride Wash Flowsheet for Treating Zirconia Calcines $\ldots \ldots \ldots \ldots \ldots$

2. Calcium Reduction Flowsheet for Treating Zirconia Calcines $\ldots \ldots \ldots \ldots \ldots \ldots \ldots$

3. Process Flowsheet for Pyrochemical Treatment of Alumina Calcine $\ldots \ldots \ldots \ldots \ldots$

\section{TABLES}

1. Calculated Normalized Composition (wt\%) and Volume of ICPP Calcined Wastes ...... 2

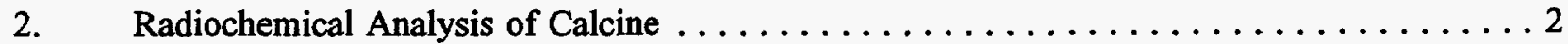

3. Percent Volatilization of Semivolatile Components in Four Calcine Types ......... 3

4. Percent Distribution of Major Elements in Calcium Chloride Wash Tests . . . . . . . 6

5. Percent Distribution of Major Elements in Calcium Reduction Tests $\ldots \ldots \ldots \ldots$

6. Mass Change Data for Zirconia Calcine Chlorination Experiments $\ldots \ldots \ldots \ldots \ldots$

7. Mass Change Observed During Calcine Chlorination Experiments ...........9 


\title{
Pyrochemical Separation of Radioactive Components from Inert Materials in ICPP High-Level Calcined Waste
}

\author{
J. A. Del Debbio \\ L. O. Nelson \\ T. A. Todd
}

\section{INTRODUCTION}

Since 1963, calcination of aqueous wastes from reprocessing of DOE-owned spent nuclear fuels has resulted in the accumulation of approximately $3800 \mathrm{~m}^{3}$ of high-level waste (HLW) at the Idaho Chemical Processing Plant (ICPP). The waste is in the form of a granular solid called calcine and is stored on site in stainless steel bins which are encased in concrete. Due to the leachability of ${ }^{137} \mathrm{Cs}$ and

${ }^{90} \mathrm{Sr}$ and possibly other radioactive components, the calcine is not suitable for final disposal. Hence, a process to immobilize calcine in glass is being developed. Since radioactive components represent less than $1 \mathrm{wt} \%$ of the calcine, separation of actinides and fission products from inert components is being considered to reduce the volume of HLW requiring final disposal. Current estimates indicate that compared to direct vitrification, a volume reduction factor of 10 could result in significant cost savings.

Aqueous processes, which involve calcine dissolution in nitric acid followed by separation of actinide and fission products by solvent extraction and ion exchange methods, are being developed. Pyrochemical separation methods, which generate small volumes of aqueous wastes and do not require calcine dissolution, have been evaluated as alternatives to aqueous processes. This report describes three proposed pyrochemical flowsheets and presents the results of experimental studies conducted to evaluate their feasibility. The information presented is a consolidation of three reports ${ }^{1,2,3}$, which should be consulted for experimental details.

\section{CALCINE CHARACTERIZATION}

Calculated compositions and volumes of ICPP calcined wastes are listed in Table $1^{3}$. As indicated, calcine consists primarily of $\mathrm{Al}_{2} \mathrm{O}_{3}, \mathrm{ZrO}_{2}$ and $\mathrm{CaF}_{2}$. This was confirmed by $\mathrm{x}$-ray analysis of alumina and zirconia calcine retrieved from bin set 2 in $1978^{4}$. Radiochemical analyses of the retrieved calcine and calcine generated from a blend of aluminum, zirconium/Fluorinel and sodium wastes during the last (6/93) calcination campaign are listed in Table 2. Due to the oxygen rich atmosphere during calcination, it is assumed that the actinides are present as oxides. Strontium-90 and ${ }^{137} \mathrm{Cs}$ may be present as fluorides and/or oxides depending on how much fluoride is present during calcination.

\section{PROCESS FLOWSHEET DEVELOPMENT}

Lockheed Idaho Technologies Company (LITCO) and Lawrence Livermore National Laboratory (LLNL) have developed several flowsheets for the separation of actinides and fission products $\left({ }^{137} \mathrm{Cs}\right.$ and ${ }^{90} \mathrm{Sr}$ ) from inerts in zirconia calcines ${ }^{2,3}$. These calcines include zirconia, Fluorinel/Na and zirconia/ $/ \mathrm{Na}$. Lockheed Idaho has developed a flowsheet for the pyroprocessing of alumina calcine in order to separate the inert $\mathrm{Al}_{2} \mathrm{O}_{3}$ from radioactive components. In this section, two selected zirconia flowsheets and the alumina calcine flowsheet will be described as well as the results of laboratory tests conducted to support the flowsheets. Also, test results for the direct chlorination of zirconia calcine to remove inerts from radioactive components are presented. 
Table 1. Calculated Normalized Composition (wt\%) and Volume of ICPP Calcined Wastes

\begin{tabular}{|c|c|c|c|c|}
\hline Component & Alumina & Zirconia & Fluorinel-Na Blend & Zirconia-Na Blend \\
\hline$\overline{\mathrm{Al}_{2} \mathrm{O}_{3}}$ & 89.5 & 14.2 & 8.9 & 13.3 \\
\hline $\mathrm{ZrO}_{2}$ & trace & 23.2 & 16.1 & 17.9 \\
\hline $\mathrm{CaF}_{2}$ & trace & 53.7 & 39.1 & 41.9 \\
\hline $\mathrm{B}_{2} \mathrm{O}_{3}$ & 0.6 & 3.0 & 2.7 & 2.4 \\
\hline $\mathrm{CdO}$ & trace & trace & 5.3 & 4.3 \\
\hline $\mathrm{Na}_{2} \mathrm{O}$ & 3.1 & trace & 4.7 & 0.9 \\
\hline $\mathrm{K}_{2} \mathrm{O}$ & trace & trace & 1.0 & 12.1 \\
\hline $\mathrm{CaO}$ & trace & 3.9 & 11.2 & 0.3 \\
\hline $\mathrm{Fe}_{2} \mathrm{O}_{3}$ & 0.6 & 0.1 & 0.2 & trace \\
\hline $\mathrm{HgO}$ & 3.1 & trace & trace & 0.3 \\
\hline $\mathrm{SO}_{4}^{=}$ & 1.2 & trace & 2.4 & 0.2 \\
\hline $\mathrm{PO}_{4}^{-}$ & trace & trace & 0.2 & trace \\
\hline Other & 1.0 & 1.0 & 0.92 & 1.0 \\
\hline Volatiles & 1.0 & 1.0 & 8.0 & 5.7 \\
\hline Radionuclides & $<1.0$ & $<1.0$ & $<1.0$ & $<1.0$ \\
\hline Volume ${ }^{a}, \mathrm{~m}^{3}$ & 765 & 1244 & 150 & 1400 \\
\hline
\end{tabular}

a. An additional $300 \mathrm{~m}^{3}$ was generated from various blends of aluminum, zirconium/Fluorinel and sodium wastes during campaign $\mathrm{H3}(6 / 93)$.

Table 2. Radiochemical Analysis of Calcine

\begin{tabular}{|c|c|c|c|c|c|c|c|}
\hline \multirow[b]{2}{*}{ Calcine } & \multicolumn{7}{|c|}{ Concentration, $\mu \mathrm{g} / \mathrm{g}$} \\
\hline & ${ }^{137} \mathrm{Cs}$ & ${ }^{90} \mathrm{Sr}$ & ${ }^{99} \mathrm{Tc}$ & Total U & Total $\mathrm{Pu}$ & ${ }^{237} \mathrm{~Np}$ & ${ }^{241} \mathrm{Am}$ \\
\hline Alumina $^{a}$ & $6.9 \mathrm{E} 1$ & 3.7E1 & ND & $5.0 \mathrm{E} 1$ & 3.2 & 5.0 & 9.7E-2 \\
\hline Zirconia $^{a}$ & $2.2 \mathrm{E} 1$ & $1.7 \mathrm{E} 1$ & ND & $3.1 \mathrm{E} 1$ & 5.9 & 1.1 & $2.5 \mathrm{E}-2$ \\
\hline 3-way blend ${ }^{b}$ & $2.8 \mathrm{E} 1$ & 2.7E1 & $2.5 \mathrm{E} 1$ & $<2.3 \mathrm{E} 2$ & $3.9 \mathrm{E}-1$ & ND & $3.9 \mathrm{E}-1$ \\
\hline \multicolumn{8}{|c|}{$\begin{array}{l}\text { a. Retrieved calcine. Values are from ICP-1189 (reference } 4) \text {. } \\
\text { b. Calcine generated during campaign H3 (6/93) from a blend of aluminum, zirconium/Fluorinel and sodium } \\
\text { wastes. Values are from INEL-94/0028 (reference 1). } \\
\text { ND - Not Determined. }\end{array}$} \\
\hline
\end{tabular}

\subsection{Volatilization of ${ }^{137} \mathrm{Cs}$ and ${ }^{99} \mathrm{Tc}$}

Removal of ${ }^{137} \mathrm{Cs}$ and ${ }^{99} \mathrm{Tc}$ from calcine prior to pyroprocessing is common to all flowsheets. Studies were conducted to evaluate removal of ${ }^{137} \mathrm{Cs}$ from calcine by high temperature volatilization. The calcines tested included simulated zirconia, alumina and Fluorinel/Na types and actual calcine generated at the New Waste Calcination Facility (NWCF). Experimental details and test results have been reported by Del Debbio ${ }^{1}$. In addition to cesium, volatilization of ${ }^{99} \mathrm{Tc}, \mathrm{Cd}$ and $\mathrm{Hg}$ was also studied. A summation of the test results is listed in Table 3. The data indicate that greater than $99 \%$ (DF $>100$ ) of the ${ }^{137} \mathrm{Cs}$ 
Table 3. Percent Volatilization of Semivolatile Components in Four Calcine Types

\begin{tabular}{|c|c|c|c|c|c|c|c|c|c|c|c|c|c|c|c|c|}
\hline \multirow[b]{2}{*}{ Temp, ${ }^{\circ} \mathrm{C}$} & \multicolumn{5}{|c|}{ Actual Calcine } & \multicolumn{4}{|c|}{ Fluorinel/Sodium } & \multicolumn{4}{|c|}{ Zirconia } & \multicolumn{3}{|c|}{ Alumina } \\
\hline & \multicolumn{2}{|c|}{900} & \multicolumn{2}{|c|}{1000} & \multirow{2}{*}{$\begin{array}{r}1170 \\
5 \\
\end{array}$} & \multicolumn{2}{|c|}{900} & \multirow{2}{*}{$\begin{array}{c}1000 \\
5 \\
5\end{array}$} & \multirow{2}{*}{$\begin{array}{r}1100 \\
5 \\
\end{array}$} & \multicolumn{2}{|c|}{900} & \multirow{2}{*}{$\begin{array}{r}1000 \\
5 \\
\end{array}$} & \multirow{2}{*}{$\begin{array}{r}1100 \\
5 \\
\end{array}$} & \multicolumn{2}{|c|}{900} & \multirow{2}{*}{$\begin{array}{r}1000 \\
5 \\
\end{array}$} \\
\hline Time, h & 5 & $10^{b}$ & 5 & $10^{\circ}$ & & 5 & 10 & & & 5 & 10 & & & 5 & 10 & \\
\hline Cs & $47 \pm 5.6$ & $59 \pm 5.4$ & $9(27 \pm 3.5)^{\circ}$ & $99(94 \pm 10)^{\circ}$ & $\begin{array}{l}99.8(380)^{\circ} \\
99.8(537)^{\circ}\end{array}$ & $84^{d} \pm 4.2$ & $94 \pm 1.0$ & $\begin{array}{l}99.7 \\
>99 \\
>99\end{array}$ & $\begin{array}{l}>99 \\
>99\end{array}$ & $22 \pm 5.5$ & $41 \pm 4.3$ & $93^{d} \pm 5.8$ & 99 & $2.5 \pm 7.0$ & $11 \pm 6.4$ & $\begin{array}{c}99 \\
>99 \\
89\end{array}$ \\
\hline Cd & $33 \pm 8.3$ & $39 \pm 7.9$ & ND & $65 \pm 4.3$ & 81,86 & $23^{d} \pm 6.3$ & $27 \pm 7.0$ & $69^{4} \pm 3.0$ & 82,83 & $11 \pm 6.2$ & $16 \pm 6.1$ & 76,76 & 86 & e & e & e \\
\hline $\mathrm{Hg}_{\mathrm{g}}$ & $>94$ & $>94$ & $>94$ & $>94$ & & & & & & & & & & & & \\
\hline${ }^{144} \mathrm{Cs}$ & $57 \pm 7.2$ & $69 \pm 6.0$ & $>99$ & $99(102 \pm 29)^{\circ}$ & & & & & & & & & & & & \\
\hline${ }^{90} \mathrm{Tc}$ & $94 \pm 1.5$ & $\mathrm{ND}$ & $94 \pm 1.2$ & $>99(>528)^{\circ}$ & & & & & & & & & & & & \\
\hline $\begin{array}{l}\text { a. Blend o } \\
\text { b. Purge } n \\
\text { c. Decontr } \\
\text { d. Averag } \\
\text { e. No Cd }\end{array}$ & $\begin{array}{l}\mathrm{I}, \mathrm{Zr} / \mathrm{Na} \text { and } \\
=0.6 \mathrm{slpm} \text {. } \\
3 \text { rums. Sta } \\
\text { due to very }\end{array}$ & $\begin{array}{l}\text { Na wastes } \\
\text { dard devis } \\
\text { small amo }\end{array}$ & $\begin{array}{l}\text { processed durin } \\
\text { ion is }=2 \sigma \text {. } \\
(0.01 \text { wt } \%)\end{array}$ & campaign $\mathrm{H3}, 3$ & & & & & & & & & & & & \\
\hline NOTES: & $\begin{array}{ll}\text { 1. } & \text { Resul } \\
\text { 2. } & \text { Purg } \\
\text { 3. } & \text { Cesin } \\
\text { 4. } & \text { ND }\end{array}$ & $\begin{array}{l}8 \text { are for } 0 \\
\text { rates }=2 \\
n \text { volatiliz } \\
\text { No data. }\end{array}$ & $\begin{array}{l}\text { e nu at stated } \\
\text { lpm except wh } \\
\text { tion data for act }\end{array}$ & $\begin{array}{l}\text { Onditions except } \\
\text { re noted. } \\
\text { tal calcine based }\end{array}$ & $\begin{array}{l}\text { where indicate } \\
\text { on }{ }^{157} \mathrm{Cs} \text { analy }\end{array}$ & $\begin{array}{l}\text { d differentl] } \\
\text { sis. }\end{array}$ & & & & & & & & & & \\
\hline
\end{tabular}


and ${ }^{99} \mathrm{Tc}$ can be removed from calcine by heat treatment at $1000-1170^{\circ} \mathrm{C}$. A decontamination factor of 100 is sufficient to allow the calcine to be designated a Nuclear Regulatory Commission (NRC) Class B low-level waste (LLW) with respect to ${ }^{137} \mathrm{Cs}$. Condensed cesium compounds were soluble in water, which suggests that collection of cesium by aqueous dissolution of the condensate followed by sorption on zeolite is feasible. Technetium condensates are expected to be soluble in water and can be treated in the same manner ${ }^{1,5}$. Condensed cadmium compounds (principally $\mathrm{CdO}$ ) were not soluble in water but dissolved readily in $3 \mathrm{~N} \mathrm{HNO}_{3}$. As is indicated in Table 3,65-86\% cadmium volatilization can be expected during heat treatment of cadmium-containing calcines. Methods would have to be developed for collection and disposal of the cadmium.

X-ray diffraction studies of heat treated calcines indicated that no significant structural changes which would affect downstream processes had occurred.

\subsection{Calcium Chloride Wash Process for Treating Zirconia Calcines}

A process for removing actinides and fission products from zirconia calcines is schematically illustrated in Figure 1. The calcine is heat treated at $600^{\circ} \mathrm{C}$ to remove $\mathrm{H}_{2} \mathrm{O}$ and $\mathrm{CO}_{2}$ and to decompose nitrates, releasing $\mathrm{NO}_{\mathbf{x}}$. This step is sometimes referred to as calcine stabilization. Cesium-137 and ${ }^{99} \mathrm{Tc}$ are removed by volatilization at $1000-1100^{\circ} \mathrm{C}$, condensed, dissolved in water and sorbed on zeolite for incorporation into a high-level waste form. The calcine then undergoes a two-step wash cycle in which it is contacted with molten $\mathrm{CaCl}_{2}$ to dissolve the $\mathrm{CaF}_{2}$. The molten salt/calcine mixture is then filtered to separate the undissolved actinide and inert metal oxides from the molten salt. The actinide and inert metal oxides are chlorinated with $\mathrm{CCl}_{4}$ to separate the inert metals as volatile chlorides. The actinide chlorides are then reduced to metals with calcium in molten $\mathrm{CaCl}_{2}$ and separated for incorporation into a metallic wasteform or converted to oxides for producing a glass waste form.

Volatile inert metal chlorides from the chloride volatility step are thermally oxidized and disposed of as LLW. Excess $\mathrm{CCl}_{4}$ can be condensed and recycled to the chlorinator.

The $\mathrm{CaCl}_{2}$ from the wash step is separated from the $\mathrm{CaF}_{2}$ and $\mathrm{CaO}$ by aqueous dissolution. The undissolved $\mathrm{CaF}$ and $\mathrm{CaO}$ is disposed of as $\mathrm{LLW}$. The $\mathrm{CaCl}_{2}$ solution is evaporated. The condensate is recycled to the aqueous dissolution step and the $\mathrm{CaCl}_{2}$ is recycled to the wash step. Fission products are disposed of as a LLW salt.

Several $\mathrm{CaCl}_{2}$ wash experiments with simulated zirconia calcine were conducted at LLNL. The objective of the tests was to determine the feasibility of separating the $\mathrm{CaF}_{2}$ from the inert metal oxides $\left(\mathrm{Al}_{2} \mathrm{O}_{3}, \mathrm{ZrO}_{2}\right)$ by dissolution of the $\mathrm{CaF}_{2}$ in molten $\mathrm{CaCl}_{2}$ and filtering the mixture to separate the metal oxides. A porous $\mathrm{MgO}$ crucible, carbon felt and a coarse silica frit with a $90-150 \mu \mathrm{m}$ pore size were tested as filtration devices. For tests with the $\mathrm{MgO}$ crucible and silica frit, $1400 \mathrm{~g} \mathrm{of} \mathrm{CaCl}_{2}$ were added to $500 \mathrm{~g}$ calcine. Tests with carbon felt were conducted using $500 \mathrm{~g}$ of $\mathrm{CaCl}_{2}$ and $200 \mathrm{~g}$ of calcine. A summation of the test results is listed in Table 4. The results indicate that $99 \%$ of the $\mathrm{Al}_{2} \mathrm{O}_{3}$ and $\mathrm{ZrO}_{2}$ was separated from the molten salt and that $75-90 \%$ of the $\mathrm{F}\left(\right.$ as $\left.\mathrm{CaF}_{2}\right)$ dissolved in the $\mathrm{CaCl}_{2} . \mathrm{Alarge}$ amount ( $60 \mathrm{wt} \%$ ) of the oxide residues consisted of $\mathrm{CaCl}_{2}$ which did not pass through the filters. This is evidenced by the high percentage of $\mathrm{Cl}$ found in the oxide residues. Inert metal oxides coated with $\mathrm{CaCl}_{2}$ may be difficult to chlorinate. The $\mathrm{CaCl}_{2}$ may have to be remelted and chlorination conducted in the melt. 


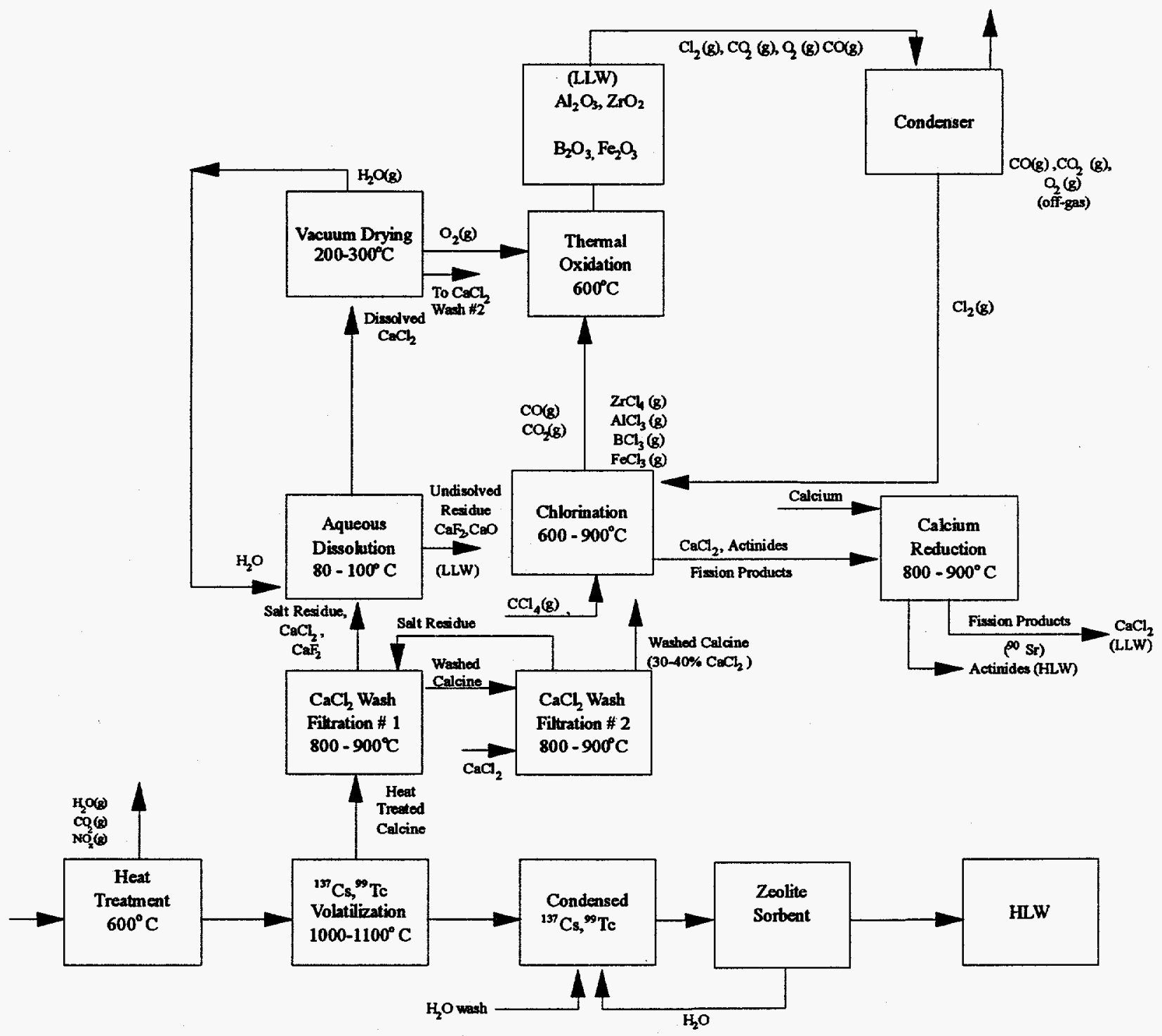

Figure 1. Calcium Chloride Wash Flowsheet for Treating Zirconia Calcines

A large percentage (69-89\%) of the $\mathrm{Sr}$ remained in the salt residue in the double wash tests. Thus, a large percentage of the ${ }^{90} \mathrm{Sr}$ would have to be disposed of as a LLW salt. The results for double wash test CWO3 indicate that greater than $93 \%$ of the Cs remained in the salt residue. However, at least $99 \%$ of the $\mathrm{Cs}$ will be removed in the volatilization step upstream of the $\mathrm{CaCl}_{2}$ wash.

Filtration rates were slow, particularly when the calcine/ $\mathrm{CaCl}_{2}$ mixture was not stirred (run CWO5). The use of coarser filters and pressurized systems to achieve acceptable filtration rates would have to be investigated. 
Table 4. Percent Distribution of Major Elements in Calcium Chloride Wash Tests

\begin{tabular}{|c|c|c|c|c|c|c|}
\hline \multirow{3}{*}{$\begin{array}{l}\text { Run \# } \\
\text { Filter } \\
\text { Filtration Rate, g/h } \\
\text { Temperature, }{ }^{\circ} \mathrm{C}\end{array}$} & \multicolumn{2}{|c|}{$\begin{array}{c}\mathrm{CWO}^{\mathrm{a}} \\
\mathrm{MgO} \text { crucible }\end{array}$} & \multicolumn{2}{|c|}{ CWO4 } & \multicolumn{2}{|c|}{$\begin{array}{c}\text { CWO5 }^{\mathrm{a}} \\
\text { carbon felt }\end{array}$} \\
\hline & \multicolumn{2}{|c|}{60} & \multicolumn{2}{|c|}{40} & \multicolumn{2}{|c|}{10} \\
\hline & & & & & & \\
\hline & $\begin{array}{c}\text { Oxide } \\
\text { Residue }\end{array}$ & $\begin{array}{c}\text { Salt } \\
\text { Residue }\end{array}$ & $\begin{array}{c}\text { Oxide } \\
\text { Residue }\end{array}$ & $\begin{array}{c}\text { Salt } \\
\text { Residue }\end{array}$ & $\begin{array}{l}\text { Oxide } \\
\text { Residue }\end{array}$ & $\begin{array}{c}\text { Salt } \\
\text { Residue }\end{array}$ \\
\hline $\mathrm{Al}$ & $>99$ & $<1$ & $>99$ & $<1$ & $>99$ & $<1$ \\
\hline $\mathrm{Zr}$ & $>99$ & $<1$ & $>99$ & $<1$ & $>99$ & $<1$ \\
\hline $\mathrm{Cl}$ & 25 & 75 & 43 & 57 & ND & ND \\
\hline $\mathbf{F}$ & $<3$ & $>97$ & 24 & 76 & ND & ND \\
\hline $\mathrm{Sr}$ & 11 & 89 & 31 & 69 & 17 & 83 \\
\hline $\mathrm{Cs}$ & $<7$ & $>93$ & ND & ND & ND & ND \\
\hline
\end{tabular}

No tests have been conducted in support of the remaining elements of the flowsheet. Chlorination of the washed calcine to separate volatile inert metal chlorides from actinide chlorides and oxidation of the inert metal chlorides to allow disposal as LLW would have to be demonstrated. Reduction of actinide chlorides in molten salts has been used extensively to produce actinide metals ${ }^{6}$. Therefore, reduction of actinide chlorides from the chloride volatility step should be feasible. However, due to the trace levels of actinides present in the calcine (see Table 2), a scavenger metal, such as cadmium, would be required to separate the reduced actinides from the molten $\mathrm{CaC1}_{2}$.

\subsection{Calcium Reduction Process for Treating Zirconia Calcines}

A flowsheet based on initial calcium reduction of the calcine to separate inert and actinide oxides from $\mathrm{CaF}_{2}$ is illustrated in Figure 2. The calcine is heat treated to remove residual $\mathrm{NO}_{\mathbf{x}}, \mathrm{H}_{2} \mathrm{O}$ and $\mathrm{CO}_{\mathbf{x}}$. Cesium-137 and ${ }^{99} \mathrm{Tc}$ are separated by high temperature volatilization. Calcium is then added to a molten $\mathrm{CaCl}_{2} /$ calcine mixture to reduce inert metal oxides $\left(\mathrm{Al}_{2} \mathrm{O}_{3}\right.$ and $\left.\mathrm{ZrO}_{2}\right)$ and actinides to metals. The metals are removed from the salt by filtration and chlorinated. Volatile inert metal chlorides are then separated from nonvolatile chlorides. The actinide chlorides are reduced to metals in molten $\mathrm{CaCl}_{2}$ with calcium, separated by filtration and incorporated into a metallic waste form. The salt residue from the first calcium reduction step is dissolved in $\mathrm{HCl}$ to convert the $\mathrm{CaO}$ generated to $\mathrm{CaCl}_{2}$ which is recycled to the calcium reduction step after vacuum drying. Inert metal chlorides are oxidized and disposed of as LLW. Fission products remain with the salt which is disposed of as LLW.

In the calcium reduction tests, about $500 \mathrm{~g}$ of heat treated $\left(\right.$ at $1000^{\circ} \mathrm{C}$ ) calcine were added to $3500 \mathrm{~g}$ of $\mathrm{CaCl}_{2}$ in a $\mathrm{MgO}$ crucible. The mixture was heated at $800-1000^{\circ} \mathrm{C}$ and stirred at $200-300 \mathrm{rpm}$. After calcium was then added in $10 \mathrm{~g}$ increments over a 30 -minute period. After calcium addition, the stirring rate was reduced to 50-100 rpm for 15 minutes to allow metal/salt phase disengagement. The stirrer was then removed and the mixture remained at temperature for $1 / 2$ hour, after which the system was allowed to cool to room temperature. The reduced metal appeared as dark particulates embedded in the salt. An attempt to separate the metal particulates by heating the metal/salt mixture to $900^{\circ} \mathrm{C}$ and filtering it through a carbon felt for 20 hours resulted in only partial separation. About $205 \mathrm{~g}$ of the salt remained 


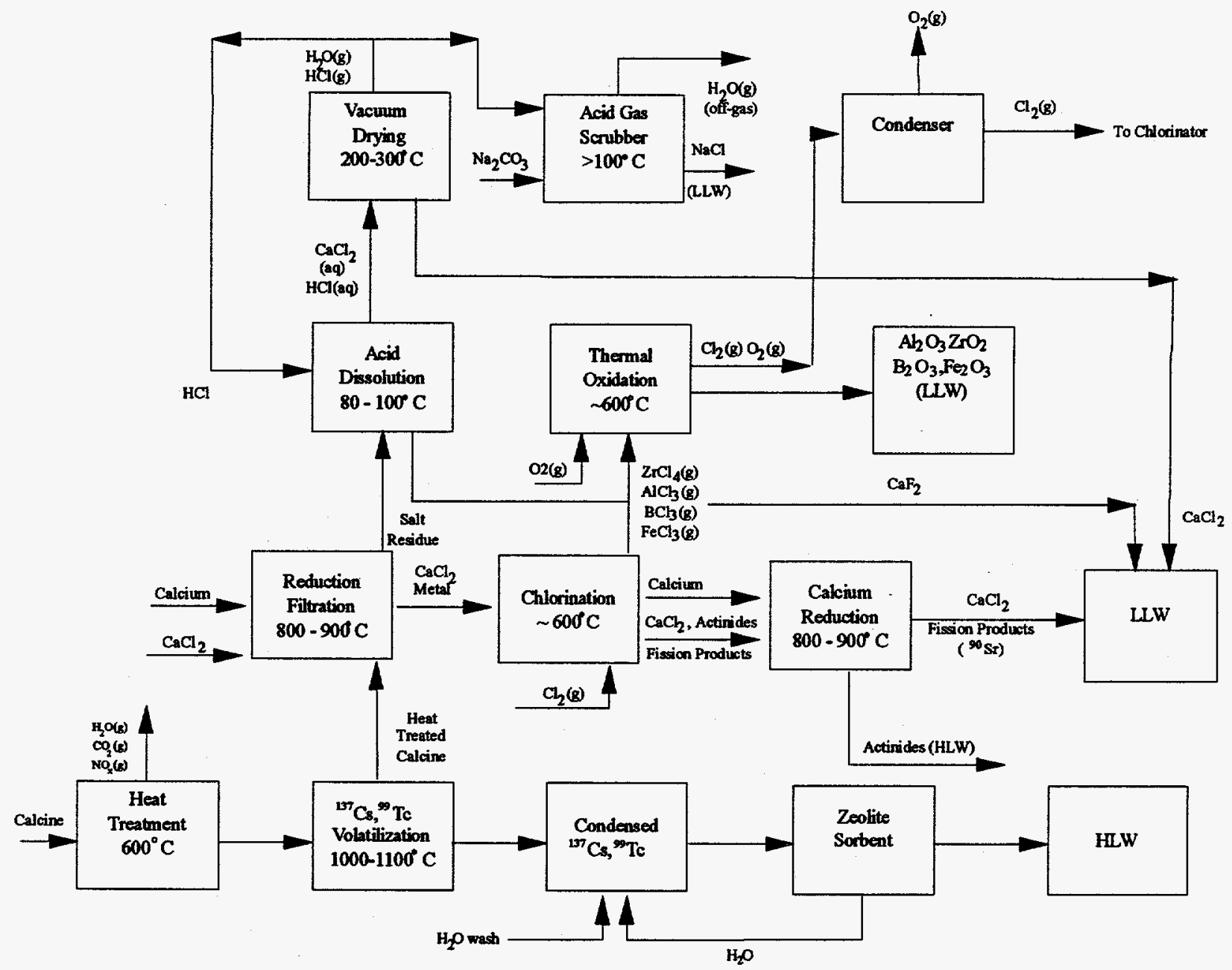

Figure 2. Calcium Reduction Flowsheet for Treating Zirconia Calcines

on the carbon felt. In order to facilitate separation of the metallic component from the salt, zinc (m.p. $400^{\circ} \mathrm{C}$ ) was added as a scavenger to coalesce the metals. The zinc failed to dissolve the metals and no metallic button was formed. Other scavenging agents such as cadmium (m.p. $320^{\circ} \mathrm{C}$ ) and nickel/cadmium alloys could be tested.

In one calcium reduction test, the portion of the salt containing the metal particulates (black salt) was separated from the remainder of the salt (white salt). The black and white salts were weighed and analyzed for major components. The elemental distribution of the major components is listed in Table 5. The data indicate that the $\mathrm{Al}_{2} \mathrm{O}_{3}$ and $\mathrm{ZrO}_{2}$ were reduced to produce $\mathrm{Al}$ and $\mathrm{Zr}$. Thus, assuming that actinides would also be reduced, calcium reduction may be feasible if the metal product could be separated from the molten salt as discussed above. The majority of the $\mathrm{Sr}$ remained in the white salt indicating that it was not reduced. The presence of $\mathrm{Sr}$ in the black salt was probably due to incomplete separation of the white and black salt. Strontium compounds are not reducible with calcium and therefore would remain in the salt which would be disposed of as a LLW in an actual process. Additional tests would have to be conducted to confirm the concentration of ${ }^{90} \mathrm{Sr}$ in the waste salt and thus determine a waste class designation. 
Table 5. Percent Distribution of Major Elements in Calcium Reduction Tests

$\begin{array}{lcc} & \text { Black Salt } & \text { White Salt } \\ \mathrm{Al} & 100 & 0 \\ \mathrm{Zr} & 95 & 4.6 \\ \mathrm{Ca} & 27 & 73 \\ \mathrm{Cl} & 27 & 73 \\ \mathrm{~F} & 50 & 50 \\ \mathrm{Sr} & 22 & 78 \\ \mathrm{Cs} & \mathrm{ND} & \mathrm{ND} \\ & & \\ & & \\ \text { a. Portion of salt containing metal particulates } & \\ \text { Reactants: Zirconia Calcine, 500.5g, CaCl } & \text { 3184.1 g, } \\ \text { Calcium, 185.1 g } & \\ \text { ND - Not Determined } & \end{array}$

\subsection{Zirconia Calcine Chlorination}

Direct chlorination of zirconia calcine to remove $\mathrm{Zr}$ and $\mathrm{Al}$ as volatile chlorides $\left(\mathrm{ZrCl}_{4}\right.$ and $\left.\mathrm{AlCl}_{3}\right)$ was evaluated. Two chlorination experiments were completed with zirconia calcine using a $\mathrm{CO} / \mathrm{Cl}_{2}$ gas mixture as the chlorinating gas. The mass change observed during these experiments is shown in Table 6. As can be seen, the calcine mass increased during chlorination. The mass increase was due to the displacement of oxygen from $\mathrm{Al}_{2} \mathrm{O}_{3}$ and a gain of chlorine according to the following reaction:

$$
3 \mathrm{CaF}_{2}+\mathrm{Al}_{2} \mathrm{O}_{3}+3 \mathrm{CO}+6 \mathrm{Cl}_{2} \rightarrow 3 \mathrm{CaCl}_{2}+2 \mathrm{AlF}_{3}+3 \mathrm{CO}_{2}
$$

The occurrence of this reaction is supported by elemental and $x$-ray analysis of the products, and by thermodynamic calculations.

Table 6. Mass Change Data for Zirconia Calcine Chlorination Experiments

$\begin{array}{ccc}\text { Run No. } & \text { Run Duration (hours) } & \begin{array}{c}\text { \% Mass } \\ \text { Change }\end{array} \\ 1 & 4 & +14 \\ 2 & 4 & +14\end{array}$

The reaction does not progress to completion because the outside layer of the calcine reacts and fuses, forming a barrier which inhibits chlorination throughout the entire particle. No further zirconia calcine chlorination experiments were conducted. However, if other pyrochemical process unit operations (e.g., direct reduction or $\mathrm{CaCl}_{2}$ wash) could be used in conjunction with chlorination of zirconia calcine, additional experiments could be conducted to determine the feasibility of zirconia calcine chlorination followed by direct reduction. 


\subsection{Chlorination of Alumina Calcine}

A schematic diagram of the pyrochemical process for treating alumina calcine is shown in Figure 3. The calcine is heat treated at $600^{\circ} \mathrm{C}$ to remove residual $\mathrm{NO}_{x}, \mathrm{H}_{2} \mathrm{O}$, and $\mathrm{CO}_{\mathrm{x}}$. The calcine is heated at $1000^{\circ} \mathrm{C}$ to remove volatile radioactive components such as ${ }^{137} \mathrm{Cs}$ and ${ }^{99} \mathrm{Tc}$. The calcine is then chlorinated with $\mathrm{CCl}_{4}$ or $\mathrm{CO} / \mathrm{Cl}_{2}$ at $600^{\circ} \mathrm{C}$ to volatilize nonhazardous, nonradioactive compounds such as $\mathrm{AlCl}_{3}, \mathrm{BCl}_{3}$, and $\mathrm{ZrCl}_{4}$. The volatilized nonradioactive components are oxidized to allow chlorine recycle and to provide a more stable LLW. The nonvolatile radioactive components are reduced, oxidized and immobilized for disposal as HLW.

Prior to chlorination experiments, a series of thermodynamic equilibrium calculations were completed. Based on equilibrium calculations for alumina calcine, the maximum separation possible was $86 \mathrm{wt} \%$ mass loss. The following reactions were predicted by the calculations:

$$
\begin{aligned}
& \mathrm{Al}_{2} \mathrm{O}_{3}(\mathrm{~s})+3 / 2 \mathrm{CCl}_{4}(\mathrm{~g}) \rightarrow 2 \mathrm{AlCl}_{3}(\mathrm{~g})+3 / 2 \mathrm{CO}_{2}(\mathrm{~g}) \\
& \mathrm{B}_{2} \mathrm{O}_{3}(\mathrm{~s})+3 / 2 \mathrm{CCl}_{4}(\mathrm{~g}) \rightarrow 2 \mathrm{BCl}_{3}(\mathrm{~g})+3 / 2 \mathrm{CO}_{2}(\mathrm{~g}) \\
& \mathrm{Na}_{2} \mathrm{O}(\mathrm{s})+1 / 2 \mathrm{CCl}_{4}(\mathrm{~g}) \rightarrow 2 \mathrm{NaCl}(\mathrm{s})+1 / 2 \mathrm{CO}_{2}(\mathrm{~g})
\end{aligned}
$$

Hence, some chlorination reactions produce volatile species such as $\mathrm{AlCl}_{3}$ and $\mathrm{BCl}_{3}$, and other reactions produce nonvolatile species such as $\mathrm{NaCl}$. A separation is achieved due to the difference in vaporization temperatures for the radioactive and nonradioactive chlorinated calcine components.

Several experiments were completed using nonradioactive alumina calcine to verify the separation by chlorination. The experimental results obtained during calcine chlorination experiments agreed well with the predictions obtained from the thermodynamic equilibrium calculations. The mass change observed during chlorination of simulated alumina calcine at $600^{\circ} \mathrm{C}$ with equimolar $\mathrm{CO}-\mathrm{Cl}_{2}$ diluted in $\mathrm{Ar}$ is shown in Table 7. As seen in Table 7, chlorination of alumina calcine resulted in a mass reduction of up to $86 \%$ due to volatilization of $\mathrm{AlCl}_{3}$ and other volatile chlorinated species.

Table 7. Mass Change Observed During Calcine Chlorination Experiments ${ }^{\mathrm{a}}$

$\begin{array}{ccc}\text { Run \# } & \text { Calcine Type } & \text { Mass Change Observed } \\ 1 & \text { Alumina } & 86 \mathrm{wt} \% \text { loss } \\ 2 & \text { Alumina } & 86 \mathrm{wt} \% \text { loss }\end{array}$

a. Experiments were completed at $600^{\circ} \mathrm{C}$ with equimolar $\mathrm{CO}-\mathrm{Cl}_{2}$ diluted in $\mathrm{Ar}$.

Two additional experiments were completed with simulated alumina calcine to determine if a separation between fission products and nonradioactive calcine components is feasible. The analytical results from these two experiments indicated that all calcine components, including Cs, volatilized from the calcine during chlorination. Hence, a clean separation between radioactive and nonradioactive components was not achieved. These results emphasize the importance of removing Cs upstream of the calcine chlorination step. 


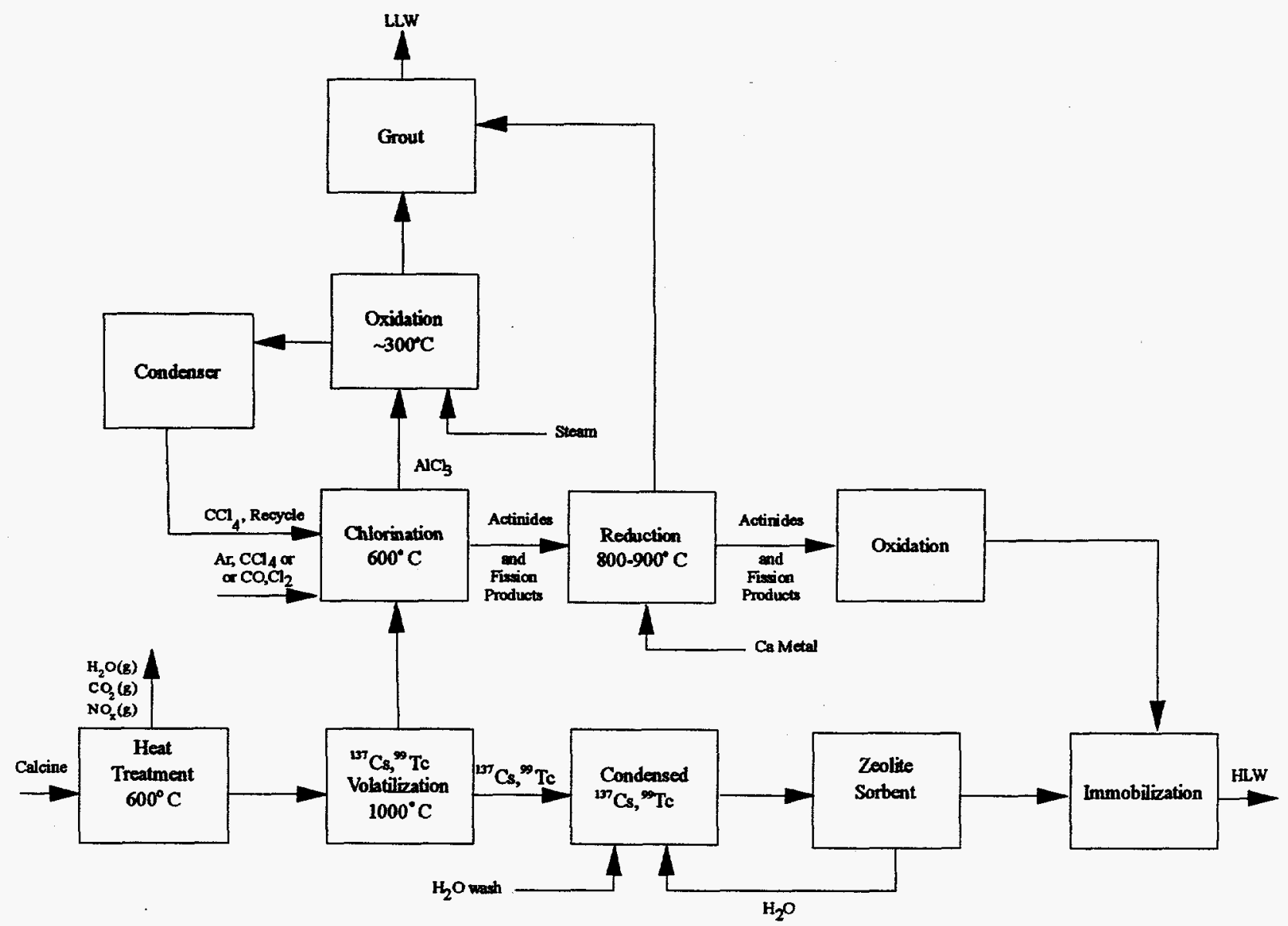

Figure 3. Process Flowsheet for Pyrochemical Treatment of Alumina Calcine

\section{CONCLUSIONS}

Tests with zirconia calcine have indicated that separation of actinides and fission products from inerts by a pyrochemical process can best accomplished with a process based on the separation of $\mathrm{CaF}_{2}$ from $\mathrm{ZrO}_{2}$ and $\mathrm{Al}_{2} \mathrm{O}_{3}$ using a $\mathrm{CaCl}_{2}$ wash (Figure 1). The $\mathrm{CaCl}_{2}$ wash is preferable to calcium reduction because of the inability to separate the $\mathrm{Al}, \mathrm{Zr}$ and $\mathrm{Cr}$ metal reduction products from the molten salt and the generation of additional $\mathrm{LLW}$ in the form of $\mathrm{NaCl}$ from the $\mathrm{HCl}$ scrubber (Figure 2). Although the $\mathrm{CaCl}_{2}$ wash was successful in separating the $\mathrm{ZrO}_{2}$ and $\mathrm{Al}_{2} \mathrm{O}_{3}$ from the molten salt, filtration rates were slow and would have to be improved significantly to make the process feasible. Separation efficiencies for ${ }^{90} \mathrm{Sr}$ are such that $70-90 \%$ would remain in the LLW salt. This condition would have to be acceptable for the process to be feasible. Chlorination of the separated inert metal oxides in residual salt and thermal oxidation of the inert metal chlorides would have to be demonstrated.

Chlorination of alumina calcine at $600^{\circ} \mathrm{C}$ to remove $90 \mathrm{wt} \%$ of the calcine as $\mathrm{AlCl}_{3}$ may be feasible. However, formation of volatile $\mathrm{UCl}_{6}$ with subsequent decomposition to $\mathrm{UCl}_{5}$ and $\mathrm{UCl}_{4}$ may occur $^{7}$. These compounds would have to be recycled to the residual calcine. Other actinide chlorides such as $\mathrm{UCl}_{3}, \mathrm{PuCl}_{3}, \mathrm{NpCl}_{3}$ and $\mathrm{AmCl}_{3}$ are expected to be stable ${ }^{8,9,10}$. Chlorination of zirconia calcine to remove $\mathrm{ZrO}_{2}$ and $\mathrm{Al}_{2} \mathrm{O}_{3}$ as volatile chlorides is not feasible. The desired reaction products, $\mathrm{ZrCl}_{4}$ and $\mathrm{AlCl}_{3}$ are not produced. 
Pyrochemical processes of the type being considered for the treatment of calcine have not achieved the advanced stage of development reached by aqueous phase processes. The pyrochemical treatment of calcine to separate actinides and fission products from inerts involves many process steps most of which have not been demonstrated. Extensive experimental studies over a number of years will be required to obtain the necessary data and acquire expertise in high temperature systems and molten salt processes. For these reasons, it is recommended that pyrochemical processes should not be given further consideration as a calcine treatment option.

\section{REFERENCES}

1. J. A. Del Debbio, Removal of Cesium from a High-Level Calcined Waste by High Temperature Volatilization, INEL - 94/0028 (November 1994)

2. M. C. Bronson, B. B. Ebbinghaus, D. C. Riley, L. O. Nelson and J. A. Del Debbio, Pyrochemical Processing of Idaho Chemical Processing Plant (ICPP) High-Level Waste (HLW) Calcine, Lawrence Livermore National Laboratory Report, UCRL-JC-119349 (November 1994)

3. L. O. Nelson, Separation of Hazardous and Radioactive Calcine Components via Chlorination, INEL-95/0146 (April 1995)

4. B. A. Staples, G. S. Pomiak and E. L. Wade, Properties of Radioactive Calcine Retrieved from the Second Calcined Solids Storage Facility at ICPP, ICP-1189 (March 1979)

5. J. A. Rard, Critical Review of the Chemistry and Thermodynamics of Technetium and Some of its Inorganic Compounds and Aqueous Species, UCRL-53440 (September 1983)

6. J. G. Reavis: in Molten Salt Techniques (D. G. Lovering and R. S. Gale, eds.), pp 38-47, Plenum Press, New York (1987)

7. J. E. Bullard and J. J. Betchul, Journal of the American Ceramic Society, Vol. 63, No. 7-8 (July-August 1980)

8. D. Brown, Halides of the Lanthanides and Actinides, pp 154-155, John Wiley and Sons (1986)

9. S. Fried, "The Preparation of Anhydrous Americium Compounds," Journal of the American Chemical Society, 73:416 (1951)

10. Plutonium Handbook: A Guide to the Technology, Volume 1, O. J. Wick, ed., p 363, American Nuclear Society (1980) 